\title{
More Rice, Less Water-Precision Water Management Approaches for Increasing Water Productivity in Irrigated Rice-Based Systems under North IGP: A Review
}

\author{
N.C. Mahajan ${ }^{1}$, R.K. Naresh ${ }^{2 *}$, S.K. Tomar ${ }^{3}$, Vivek ${ }^{2}$, Kancheti Mrunalini ${ }^{4}$, \\ M. Sharath Chandra ${ }^{2}$ and Lingutla Sirisha ${ }^{5}$
}

\author{
${ }^{1}$ Department of Agronomy, Institute of Agricultural Sciences, Banaras Hindu University, \\ Varanasi-(U.P), India \\ ${ }^{2}$ Department of Agronomy, Sardar Vallabhbhai Patel University of Agriculture \& Technology, \\ Meerut, (UP), India \\ ${ }^{3}$ KVK Belipar, Gorakhpur, Narendra Dev University of Agriculture \& Technology, \\ Kumarganj, Ayodhya, U.P., India \\ ${ }^{4}$ Department of Agronomy, Tamil Nadu Agricultural University, Coimbatore, Tamil Nadu, \\ India \\ ${ }^{5}$ Department of Agronomy, Bihar Agricultural University, Sabour, Bhagalpur-Bihar, India
}

*Corresponding author

\section{Keywords \\ Water productivity, Tillage, Water balance, Alternate wetting and drying \\ Article Info \\ Accepted: \\ 15 April 2019 \\ Available Online: \\ 10 May 2019}

\section{A B S T R A C T}

Water is a critical input for productivity enhancement especially of field crops. Its judicious and optimum use is needed utmost for realizing higher resource use efficiency and plugging gaps in production. Key technological interventions, which could alter or rectify the usage pattern or strategies in freshwater utilization in agriculture, are the need of the hour. Precision water management approach could help in conserving and making more-efficient use of scarce water resources through integrated management combined with selected external inputs/technologies. In this context, the scientific interventions on water management involving precision levelling of land, no tillage or reduced tillage systems, furrow irrigated raised bed planting systems and other inclusive technological practices could enforce appropriate water management schedules. The potentials for water savings in rice production appear to be very large. But we do not know the degree to which various farm and system interventions will lead to sustainable water savings in the water basin until we can quantify the downstream impact of the interventions. Studies on the economic benefits and costs of alternative interventions are also lacking. Without this additional information, it will be difficult to identify the potential benefits and the most appropriate strategies for increasing irrigation water productivity in rice-based systems. During the crop growth period, the amount of water usually applied to the field is much more than the actual field requirement. When water supply within the irrigation system is unreliable, farmers try to store much more water in the field than needed as insurance against a possible shortage in the future. Rice transplanted on wide raised beds and transplanted rice under reduced tillage plots consumed more moisture from the deeper profile layer than conventional tillage practice Transplanted basmati rice after puddling recorded higher bulk density and more contribution from top layer. Dry-seeded rice technology offers a significant opportunity for conserving irrigation water by using rainfall more effectively. The future of rice production will therefore depend heavily on developing and adopting strategies and practices that will use water efficiently in irrigation schemes. This review paper emphasizes the need for integrating various water-saving measures into practical models and for conducting holistic assessments of their impact within and outside irrigation systems in the water basin. 


\section{Introduction}

Water is one of the essential inputs for crop production as it affects plant development by influencing its vital physiological processes. For realizing potential yield of any crop, it must not be allowed to suffer from water stress at any of the critical growth stages. Water stress, especially at reproductive stages, may substantially reduce the yield (O'Toole, 1982). On the other hand, water should also be utilized efficiently for getting higher yield per unit of water applied. Thus, proper scheduling of irrigation should be aimed at eliminating over- or under- irrigation and ensuring optimum yields with high water productivity. Water management has a significant influence on rice growth, grain production and water productivity. There is a possibility of reducing water requirement of rice without affecting grain yield in comparison to continuous submergence. Intermittent irrigation appears to be as effective as continuous submergence. Several studies reported a positive effect of intermittent aerobic conditions on flooded rice growth (Lin et al., 2005) indicating that continuous flooding may not be the best method of irrigating rice (Horie et al., 2005). Rice is significantly more sensitive to water deficit than other grain crops (Inthapan and Fukai, 1988). Flood-irrigated rice utilizes two or three times more water than other cereal crops such as wheat and maize.

Bouman et al., (2005) studied that on average, aerobic fields used $190 \mathrm{~mm}$ less water in land preparation, and had 250-300 $\mathrm{mm}$ less seepage and percolation, $80 \mathrm{~mm}$ less evaporation, and $25 \mathrm{~mm}$ less transpiration than flooded fields. Jalota et al., (2006) observed that reducing evapo-transpiration (ET) through deficit irrigation and identification of the most sensitive crop growth stage to water stress has been reported as one of the way to enhance crop water productivity (CWP). Shekara et al., (2010) studied the response of aerobic rice to different irrigation regimes based on irrigation water (IW) to cumulative pan evaporation (CPE) ratios of 2.5, 2.0, 1.5 and 1.0 and found that irrigation scheduled at IW/CPE ratio of 2.5 recorded higher grain yield $(6.2$ and $6.6 \mathrm{t}$ $\left.\mathrm{ha}^{-1}\right)$ and required more water $(154.8 \mathrm{~cm})$ leading to lower water productivity $(41.3 \mathrm{Kg}$ $\mathrm{ha}^{-1} \mathrm{~cm}^{-1}$ ) whereas irrigation scheduled at IW/CPE ratio of 1.0 required less water $(91.84 \mathrm{~cm})$ with higher water productivity (52.1 Kg ha $\left.{ }^{-1} \mathrm{~cm}^{-1}\right)$. Yadav et al., (2011) revealed that the irrigation water use efficiency was higher in alternate wetting and drying (AWD) than daily irrigated treatments. It was also found that irrigation scheduling at $20 \mathrm{KPa}$ soil water tension results in 33-53 per cent saving of irrigation water in dry directseeded rice than transplanted rice. The yield component of DSR and PTR were similar when irrigation was scheduled daily and at 20 $\mathrm{KPa}$ soil moisture tension. In China, the water use for aerobic rice production was 55-56 per cent lower than the flooded rice with 1.6-1.9 times higher water use efficiency. Bouman $e t$ al., (2005) carried out experiments at Philippines and reported that water inputs in aerobic rice system were 30-50 per cent less than in flooded system with yields 20-30 per cent lower, with a maximum of about $5.5 \mathrm{t}$ $\mathrm{ha}^{-1}$ and evaporation losses were reduced on the order of 50-75 per cent which results in higher water productivity with aerobic rice than flooded rice.

\section{Irrigation scheduling and water use}

Wang et al., (2002) and Bouman et al., (2005) concluded that potential yield of any crop; it must not be allowed to suffer from water stress at any critical growth stage. But, water should also be utilized efficiently for getting higher yield per unit of water applied. There is possibility of reducing water requirement of rice without affecting the grain yield in 
comparison to the continuous sub-mergence. Aerobic rice systems can reduce water application by 44 per cent relative to conventional transplanted systems, by reducing percolation, seepage and evaporative losses, while maintaining yield at an acceptable level $\left(6 \mathrm{mg} \mathrm{ha}^{-1}\right)$. Singh et al., (2005) reported that after germination of direct seeded rice (DSR), irrigation can be delayed for around 7-15 days depending on soil texture. Delayed irrigation facilitates deeper rooting and makes seedlings resistant to drought. Water requirement and ponding of water requirement is very low in case of DSR, irrigation frequency of 3-7 days after the disappearance of water from the field can be practiced. Under limited water supply and drought situations, irrigation can be delayed up to 10-15 days, but care should be taken that irrigation is crucial once tillering has begun. Balasubramanian et al., (2001) conducted a field experiment at Tamil Nadu Agricultural University, Coimbatore, India, with nine levels of irrigation and found that grain yield was the highest with irrigation of 5- $\mathrm{cm}$ depth at 1 day after the disappearance of ponded water in direct seeded rice and transplanted rice. Water use was the maximum with transplanted rice due to extended land preparation and nursery raising. Whereas in field experiments conducted on DSR to study effect of different water management practices on water use, the results revealed that the WUE was resulted optimum when submergence was done continuously at depth of $2.5 \mathrm{~cm}$ along the complete cropping period as the irrigation schedule was not significantly different from $5 \mathrm{~cm}$ depth. Sudhir-Yadav et al., (2011) found that irrigation water productivity was higher in alternate wetting drying (AWD) than in daily irrigated treatments. Due to large reductions in irrigation water amount from 40 and $70 \mathrm{kPa}$ irrigation schedules, there was reduction in the grain yield. There was a large effect of both treatments on irrigation water productivity (WPI). However, WPI irrigated at $20 \mathrm{kPa}$ was significantly higher than all other treatments. Input water productivity (WPI+R) was much lower than WPI in the respective treatments each year due to the large amount of rainfall each year. Matsuo and Mochizuki (2009) revealed that continuously flooded paddy (CF), alternate wetting and drying system (AWD) in paddy field and aerobic rice systems in which irrigation water was applied when soil moisture tension at $15 \mathrm{~cm}$ depth reached -15 $\mathrm{kPa}$ and $-30 \mathrm{kPa}$ and resulted that total water applied was $2145 \mathrm{~mm}$ in CF, $1706 \mathrm{~mm}$ in AWD, $804 \mathrm{~mm}$ in aerobic rice.

Singh et al., (2002) revealed that irrigation water use efficiency was higher at $20 \mathrm{KPa}$ soil moisture tension (37 $\mathrm{Kgha}^{-1} \mathrm{~cm}^{-1}$ ) than saturation and $40 \mathrm{KPa}$ soil moisture tension. Jat et al., (2009) also found reduced water input (irrigation plus rainfall) by 9-24 per cent with direct-seeded rice in comparison with puddled transplanted rice. Tabbal et al., (2002) reported that direct-seeded rice required 19 per cent less water than puddled transplanted rice during the crop growth period and increased water use efficiency by 25-48 per cent with continuous standing water conditions. Cabangon et al., (2002) compared the water input and water productivity of transplanted and direct-seeded (dry and wet seeded) rice production system and reported that dry-seeded rice had significantly less irrigation water and higher water use efficiency as compared to wet seeded and transplanted rice production system. Kumar et al., (2013) observed that the substantial water saving 41 to $94 \mathrm{~mm} / \mathrm{ha}$ in 2010 and 86 to 144 $\mathrm{mm} / /$ ha in year 2011 was recorded with all the micro irrigation systems. The highest water productivity was recorded with sprinkler irrigation system than remaining irrigation techniques during both the study years. No yield penalty was recorded under micro irrigation systems. The performance of 
drip and sprinkler irrigation on yield contributing charter and yield was found at par with flood irrigation.

Mao Zhi (2000) reported that three essential water efficient irrigation regimes (WEI) for rice as shown in Figure 1, which include the regimes of combining shallow water depth with wetting and drying(SWD), alternate wetting and drying (AWD) and semi-dry cultivation (SDC). In comparison to the traditional irrigation regime (TRI), rice yield can be increased slightly, water consumption and irrigation water use of paddy field can be decreased greatly and the water productivity of paddy field can be increased remarkably under the WEI. The main causes of decrease of water consumption and irrigation water use are the decrease of the percolation rate in paddy field and increase in the utilization of rainfall.

A positive environmental impact is obtained by adopting WEI, the main cause of getting bumper yields were that the ecological environment under WEI is more favourable for the growth and development of rice than that under TRI.

Reducing seepage and percolation flows through reduced hydrostatic pressure can be achieved by changed water management (Bouman et al., 1994). Instead of keeping the rice field continuously flooded with $5-10 \mathrm{~cm}$ of water, the floodwater depth can be decreased, the soil can be kept around saturation (SSC; saturated soil culture), or alternate wetting and drying (AWD) regimes can be imposed. Soil saturation is mostly achieved by irrigating to about $1 \mathrm{~cm}$ water depth a day or so after disappearance of standing water. In AWD, irrigation water is applied to obtain $2-5 \mathrm{~cm}$ floodwater depth after a larger number of days (ranging from 2 to 7) have passed since disappearance of ponded water. The level of yield decrease depends largely on the groundwater table depth, the evaporative demand and the drying period in between irrigation events (in the case of AWD). Mostly, however, relative reductions in water input are larger than relative losses in yield, and, therefore, water productivities with respect to total water input increase.

\section{Crop and soil monitoring for precision water management}

Water requirement varies with the crop and crop growth and development status, soil water status, as well as environmental conditions. Closely monitoring soil water status, crop growth conditions and their spatial and temporal patterns can aid in irrigation scheduling and precise water management.

Among many tools, remote sensing can serve an effective basis by providing images with spatial and temporal variability of crop growth parameters and soil moisture status for input in precision water management. Various indices derived from thermal and multispectral images, such as crop water stress index (CWSI), perpendicular vegetation index (PVI), normalized difference vegetation index (NDVI) and photochemical reflectance index (PRI), can predict soil or plant water status and drought stress as a basis for sitespecific water management (Marino et al., 2014; Masseroni et al., 2017). Use of digital infrared thermography to measure canopy temperature can help producers to detect early crop water stress and avoid yield declines as well as saving water with site-specific irrigation management and irrigation scheduling (O'Shaughnessy et al., 2011 \& 2012).

\section{Precision water management strategies}

Several precision irrigation technologies have been developed to improve crop productivity under water-limited conditions. However, 
appropriate precision irrigation strategies are equally important for increased efficiency and profitability for site-specific technologies. The development and application of management zones using spatial and temporal information of various agronomic factors have been practiced for site-specific management for several decades. In recent years, the use of artificial intelligence in prescription map development for sitespecific water management is also increasing. Rowshon and Amin, (2010) observed that the right amount of daily irrigation supply and monitoring at the right time within the discrete irrigation unit is essential to improve the irrigation water management of a rice plots. The GIS capability to achieve the goal in the view of irrigation strategy and goal with special reference to precision farming of rice. Good water management means the applying the precise amount of water at the right time and the right place and its proper performance evaluation. Effective utilization of available water resources for irrigation supplies and impartial water allocation with suitable water management practice are the key factors for increasing rice production (DID and JICA, 1998).Precise application of water to meet specific requirements of individual plants or management units and minimize adverse environmental impact (Raine et al., 2007).

A lot of water is used in the production of rice as the staple food of more than half the world population. However, despite the constraints of water scarcity, rice production must be raised to feed the growing population. Producing more rice with less water through appropriate precision irrigation technology is a formidable challenge for food and water security. The most populous and rice producing and consuming countries like India and China are approaching the limit of water scarcity. In these countries about $84 \%$ of water withdrawal is for agriculture, with major emphasis on flooded irrigation for rice. It is high time that the two countries start adopting precision irrigation methods for growing paddy. Gathala et al., (2014) zerotillage direct-seeded rice (ZT-DSR) with residue retention and best management practices provided equivalent or higher yield and 30-50 per cent lower irrigation water use than those of farmer-managed puddled transplanted rice (CT-TPR). Pathak et al., (2013) reported that DSR saved 3-4 irrigations compared to the transplanted rice without any yield penalty.

The DSR on raised beds decreased water use by 12-60 per cent, and increased yield by 10 per cent as compared to PTR, in trials at both experimental stations and on-farm (Gupta et al., 2002). Water productivity in DSR was 0.35 and 0.76 as compared to 0.31 and 0.57 under PTR during 2002 and 2003, respectively, indicating better water-use efficiency (Gill et al., 2006).

In DSR, crop established after applying presowing irrigation, first irrigation can be applied 7-10 days after sowing depending on the soil type. When DSR crop is established in zero tilled (ZT) conditions followed by irrigation, subsequent 1-2 irrigations are required at interval of 3-5 days during crop establishment phase. Subsequent irrigations at interval of 5-7 days need to be applied in DSR crop. During active tillering phase i.e. 30-45 days after sowing (DAS) and reproductive phase (panicle emergence to grain filling stage) optimum moisture (irrigation at 2-3 days interval) is required to be maintained to harvest optimum yields from DSR crop. In a 6-year study conducted in Modipuram on sandy-loam soil, it was observed that dryDSR can be irrigated safely at the appearance of soil hairline cracks (Gathala et al., 2011).

Drill seeding of rice and wheat on reduced-till flat land (RT-DSR/RT-DSW) or on raised 
beds (Bed-DSR/Bed-DSW) saved irrigation or total water use by 62 to $532 \mathrm{~mm} \mathrm{ha}^{-1}$, but was less productive than conventional practices; yield loss was high in narrow raised bed planted crops (Naresh et al., 2013). Although total productivity was less in zerotill drill seeded rice and wheat (ZT DSR/ZTDSW: by 1.08 to $1.3 \mathrm{t} \mathrm{ha}^{-1}$ ), water savings were high because of lower irrigation water need. These results are consistent with previous studies (Ladha et al 2009). This suggests a need for further research to perfect double zero-tillage systems and promising options irrigation. Dry direct seeding and zero-tillage rice-wheat system had a savings in labor, input use water requirement and machine use. Conventional practice of puddled transplanting could be replaced by unpuddled and zero-till-based crop establishment methods to save water and labor and achieve higher income (Naresh et al., 2013).

\section{Development of site-specific water management strategies}

Anbumozhi et al., (1998) on the effects of continuous, intermittent and variable ponding and also under different doses of fertilizer application on rice have shown that at $9 \mathrm{~cm}$ ponding depth, grain yield of 5.2 and $4.95 \mathrm{t} / \mathrm{ha}$ were obtained with continuous and intermittent ponding, respectively. AWD irrigation resulted in higher water productivity of $1.26 \mathrm{~kg} / \mathrm{m}^{3}$ compared to continuous flooding $\left(0.96 \mathrm{~kg} / \mathrm{m}^{3}\right)$. Qinghua et al., (2002) reported that intermittent irrigation reduced rice yield by $4-6 \%$ than the flooded treatment. Water saving in alternately submerged and non-submerged irrigation was 13-16\% compared with continuously submerged regime. Sattar et al., (2009) reported that the water productivity was about $30 \%$ higher under AWD compared with farmers' practice of continuous standing water. Naresh et al., (2010) reported that the saving in water use with the beds was $16.26 \%$ compared to conventional paddled transplanted rice, he also found that the total system water used was remarkably lower with beds compare to other practices but the maximum water used was recorded with puddle transplanted rice he also observed that reduce tillage operations with alternative crop establishment methods such as direct seeding on flat land and raised beds can result in significant water saving and to increase water productivity.

Sandhu et al., 2012; Gathala et al., (2013) reported that Irrigation water productivity (IWP) was significantly higher in beds to the tune of $13.9 \%$ and $13.16 \%$ than flat puddled planting. He also revealed that the rice transplanted on beds required $15.4 \%$ and $15.3 \%$ less irrigation water than that required in puddled plots. The reduction in amount of irrigation water applied in beds may be attributed to the less depth of irrigation water application to beds $(5 \mathrm{~cm})$ as compared to puddled plots $(7.5 \mathrm{~cm})$. Naresh et al., (2014) revealed that different crop establishment techniques, conventional-tilled puddle transplanted rice (CT-TPR) required $14 \%-25 \%$ more water than other techniques. Compared with the CT-TPR system, zero till direct-seeded rice (ZT-DSR) consumed 6\%$10 \%$ less water with almost equal system productivity and demonstrated higher water productivity. Similarly, wide raised beds saved about $15 \%-24 \%$ water and grain yield decrease of about $8 \%$.

Singh et al., (2014) established the preparation of land for transplanting paddy (puddling) consumes about 20-40\% of the total water required for growing of crop and subsequently poses difficulties in seed bed preparation for succeeding wheat crop in rotation. It also promotes the formation of hard pan which effects rooting depth of next crop. Linquist et al., (2015) reported about $15 \%$ of applied water being lost to percolation 
and seepage. Furthermore, in cases where AWD is practiced during the wet season a $25.7 \%$ reduction in total water use might translate into an even greater reduction in irrigation water use. For example, during a period where the soils are not flooded, a rain event during that time is less likely to result in surface runoff and can delay the time required until irrigation may be needed to re-flood the field (Massey et al., 2014). Nalley et al., (2015) revealed that an accounting for the water savings $(-27.5 \%$ relative to $\mathrm{CF})$ being greater than the reduction in yield $(-5.4 \%$ relative to $\mathrm{CF}$ ), water productivity was $24.2 \%$ higher in AWD than in CF. Considering only Mild AWD, water productivity was $25.9 \%$ higher than $\mathrm{CF}$. With water resources becoming increasingly limited this is an important benefit of AWD. However, depending on the cost of water and rice, higher water productivity does not necessarily indicate that a practice is more economical for a farmer. The economic viability of different AWD treatments and found the lowest profit in the treatment with highest water productivity. Thus, other factors besides water productivity need to be considered. Reduced water use in AWD systems can be attributed, at least in part, to reduced percolation and seepage. Percolation and seepage are significantly reduced in the absence of flood water; however, such losses are highly dependent on the hydrological properties of a given soil.

Zhao et al., (2015) observed that the total water use of continuously flooded rice in some plots varied up to more than two fold as much between seasons and, in general terms, they attributed this difference to different meteorological occurrences and soil behaviour. Belder et al., (2007) reported more than a two-fold variation in water requirements of alternately submerged-nonsubmerged rice when a deep drain was excavated in order to increase internal drainage and lower the groundwater table. Values of water use efficiencies (evapotranspiration over net water input) and water productivity (grain yield over net water input) were therefore in the order WFL $<$ DFL $<$ DIR. The latter reached a water use efficiency of $0.56 \mathrm{~mm} \mathrm{~mm}-1$ and a water productivity of $0.88 \mathrm{~m}^{3} \mathrm{ha}^{-1}$. Zhang et al., (2009) reported an increase in rice yield by $11 \%$ (when compared to the CF) when AWD was applied each time the soil matric potential reached $15 \mathrm{kPa}$ at $15-$ $20 \mathrm{~cm}$ and yield reduction by $32 \%$ under AWD applied each time soil matric potential reached $30 \mathrm{kPa}$ at $15-20 \mathrm{~cm}$.

\section{Integrated water resource management}

Options must recognize that the allocation of water resources to the rice sector is firmly inserted in an integrated water resource management framework that gives equal opportunity to sectors other than rice. Water allocation decisions at basin, system and farm level are made on economic, technical, social and legal grounds, and investment into water management must adhere to a set of national policies concerning food, poverty and environmental issues. Careful consideration is to be given to linkages between the levels concerned, in order to meet water demand and supply the needs of rice-based systems. Linkages exist between the various levels: a higher level supplies water to the lower level, which demands water from the higher level. Thus, an intervention that changes demand at one level should be matched by a corresponding change in supply at the upper level. The notion of service may be introduced to describe the linkages between the various levels, each level providing a water delivery service to the next, lower level, from basin down to farm level. Therefore a guiding principle of the conceptual framework is the integration of supply and demand management options at all levels including basin, system and field, and 
application of a consistent service-oriented approach.

\section{Improving service quality through modernization and improved management}

"A modern design is the result of a thought process that selects the configuration and physical components in light of a welldefined and realistic operational plan that is based on the service concept. A modern design is not defined by specific hardware components and control logic, but use of advanced concepts of hydraulic engineering, irrigation, agronomy and social science should be made to arrive at the most simple and workable solution".

\section{Optimizing water re-use systems through recycling and conjunctive use of groundwater}

Field-to-field irrigation is regarded as a prime example for a re-use system, although it may also be considered that the final distribution stage consists of several fields. Another example is conjunctive use of groundwater resources to supplement irrigation supplies for dry-season crops including rice. Assuming an efficiency of 40 percent, the system efficiency could be raised by 10 percent if only onequarter of the seepage and percolation is recyclable. Water re-use systems could be introduced to all main rice ecologies. In Asia, over 40 percent of the irrigated area is supplied by groundwater, most of which is found in India where it is used year-round to satisfy intensified rice-wheat systems. It is estimated that aquifers support 60 percent or more of the food grown on irrigated land in India, which is about 50 percent of India's total food production (Seckler, 1999). The positive effects of groundwater exploitation are that it is an easy means to get access to a large extra resource and, when developed privately, it provides the flexible and reliable water delivery service farmers require $(\mathrm{FAO}$,
2002). Shallow tube-well irrigation, on the other hand, is generally highly profitable. However, many of the aquifers in India are being depleted and in some cases the drawdown is over $1 \mathrm{~m}$ per year, and there is concern about the degradation of resources due to salt. Where groundwater is a water sink, conjunctive use cannot be applied for water quality reasons.

The management of conjunctive-use systems may represent a feasible alternative to improving the performance of the surface systems, but it entails difficulties:

- First, the prevention of overexploitation requires recharge of aquifers through controlled or uncontrolled recharge; about one-half of the recharge of aquifers is from the outflow of the irrigation systems, the other half from rainwater.

- Second, intensification of rice-based systems implies increased use of fertilizers and pesticides which travel downwards, along with seepage and recharge water, especially on the lightto medium-textured soil of the Indus Basin.

- Third, the use of groundwater is largely dependent on quality: if groundwater is saline, there is a serious risk of resource degradation.

The reduction by $10 \%$ of water used for rice irrigation would save 150,000 million $\mathrm{m}^{3}$, which corresponds to about $25 \%$ of the total fresh water globally used for non-agricultural purposes (Klemm, 1998). Transplanted Irrigated rice requires a lot of water for puddling, transplanting and irrigation and significant water losses can occur through seepage, percolation and evaporation, it is estimated that it consumes 3000-5000 liters of water to produce $1 \mathrm{~kg}$ of rice (Barker et al., 1998). 
Kadiyala et al., (2012) reported that the total amount of water applied (including rainfall) in the aerobic plots was 967 and $645 \mathrm{~mm}$ compared to 1546 and $1181 \mathrm{~mm}$ in flooded rice system, during 2009 and 2010, respectively. This resulted in 37 to $45 \%$ water savings with the aerobic method. Jinsy et al., (2015) found that compared to conventional flooded rice, the average water productivity of aerobic rice $\left(0.68 \mathrm{~kg} \mathrm{~m}^{3}\right)$ was 60.7 per cent higher. Reddy et al., (2010) reported that water productivity was higher under aerobic ( 0.20 to $0.60 \mathrm{~kg} \mathrm{~m}^{-3}$ of water) than that under transplanted ( 0.14 to $0.43 \mathrm{~kg} \mathrm{~m}^{-3}$ of water) condition. Aerobic rice could be successfully cultivated with $600-700 \mathrm{~mm}$ of total water in summer and entirely on rainfall in wet season (Sritharan et al., 2010). The reduction in irrigation water use varied with type of DSR method, ranging from $139 \mathrm{~mm}(12 \%)$ in wet seeding on puddled soil (CT-wet-seeding) to 304-385 mm (21-25\%) in dry seeding after tillage (CT-dry-seeding) or zero tillage (ZTdry-seeding), and $474 \mathrm{~mm} \mathrm{(33 \% )} \mathrm{in} \mathrm{dry}$ seeding on raised beds (Bed-dry-DSR). In CT-TPR, the field is generally kept continuously flooded (Fig. 4A). Whereas in Wet-DSR, during the first 10 days, very little or no irrigation is applied and then irrigation is either applied at 2- to 3-day intervals or relatively shallow flooding is maintained during the early part of vegetative growth to avoid submergence of young seedlings, thereby reducing seepage, percolation, and evaporation losses. Moreover, the Wet-DSR crop is harvested about 10-15 days earlier than CT-TPR; therefore, total duration from seed to seed is reduced in this method (Fig. 4B). In Wet-DSR, the main field is soaked, and the land is prepared 2-3 days prior to sowing. In Dry-DSR, lower water use than that in CT-TPR may be attributed to savings in water used for puddling in CT-TPR and the AWD irrigation method instead of continuous flooding in CT-TPR (Fig. 4C).
Puddling breaks capillary pores, destroys soil aggregates, and disperses fine clay particles and form a hard pan at shallow depth. It is beneficial for rice as it control weeds, improves availability water and nutrient, facilitates transplanting and results in quick establishment of seedlings. (De Datta,1981) reported that puddling is known to be beneficial for growing rice, it can adversely affect the growth and yield of subsequent upland crops because of its adverse effects on soil physical properties, which includes poor soil structure, sub-optimal permeability in the lower layers and soil compaction. Gathala et al., (2011) observed that the harmful effects of puddling on ensuing crops increased interest in shifting from CT-PTR to Dry-DSR on ploughed soil (No puddling) or in ZT conditions, where an upland crop is grown after rice. Ladha et al., (2009) revealed that this is especially relevant to the rice-wheat system in which land goes through wetting and drying phenomenon. It, therefore, becomes imperative to identify alternative establishment method to puddling especially in those regions where water is becoming scarce, and an upland crop is grown after rice.

\section{Effect of ground-cover rice production system on water saving and grain yield}

In plastic film mulching (PFM), also called lowland rice varieties are used and the soil is kept humid by covering materials (Kreye et al., 2007). Nevertheless, the amount of water saved with this system can be as high as 60$85 \%$ of the need in the traditional paddy systems with no adverse effects on grain yield (Huang et al., 1999). However, some researcher reported significant yield reductions under such conditions (Borrell et al., 1997). Thereafter, to check evaporation the soil surface is covered by material, such as plastic film, paper, or plant mulch (Lin et al., 2003). Although benefits of water-saving rice cultivation in water-limited areas have been 
illustrated, other experimental evidences suggest moderate to severe yield reduction (Borrell et al., 1997) of water-saving cultivation compared to paddy. With lower soil water potentials the elongation of internodes, the number of panicles and the crop growth rate reduced in comparison to flooded conditions (Lu et al., 2000). Lin et al., 2003 recorded up to $60 \%$ reduction in water requirements of rice crop; however, grain yields were up to $10 \%$ lower than the traditional lowland rice. This was associated to micronutrient deficiency and difficulties in nitrogen fertilizer management contributed to higher yield penalty.

\section{Raised beds system for water saving in rice}

Currently, puddling induces high bulk density, high soil strength and low permeability in subsurface layers (Kukal and Aggarwal, 2003). These factors restrict root development, water and nutrient use from the soil profile by wheat sown after rice. The development of hardpan also leads to aeration stress in wheat crop at the time of the first irrigation and this problem is predominant in the region where rice-wheat system is being practiced. Thus, puddling in rice results in reduced grain yield of succeeding wheat crop (Borrell et al., 1997).

Various technologies for water saving in rice like direct seeding, ground cover system, alternate wetting and drying, direct seeding and transplanting on beds (soil saturation culture), etc. are being tested. The latter one, i.e. transplanting of rice on beds omits puddling and hence avoids the detrimental effects of puddling. In this case rice is grown on raised beds and irrigation is applied in furrows between the beds. Although, numerous studies suggest water saving associated with plant installation in beds, water management (continuously flooded condition or intermittent irrigation) is often poorly reported. This is an important consideration in assessing whether the raised beds saved irrigation water because of their particular geometry or whether the water saving was the result of applied intermittent irrigations which can also be applied to flat land [38]. Transplanting of rice seedlings on slopes of freshly constructed beds resulted in $15 \%$ saving of irrigation water as compared to puddled plots (conventional method used by farmers) without any significant reduction in grain yield of rice. Irrigation water can also be saved in puddled transplanted rice by applying irrigation three days after disappearance of ponded water as compared to recommended practice of applying irrigation two days after disappearance of ponded water and this practice does not leads to any significant reduction in grain yield. However, beds are to be irrigated two days after disappearance of ponded water (Sandhu et al., 2012).

Singh et al., (2001) evaluated the yield and water use of rice established by transplanting, wet and dry seeding with subsequent aerobic soil conditions on flatland and on raised beds. Transplanted rice yielded 5.5 tha $^{-1}$ and used $360 \mathrm{~mm}$ of water for wetland preparation and $1608 \mathrm{~mm}$ during crop growth. Compared with transplanted rice, dry-seeded rice on flatland and on raised beds reduced total water input during crop growth by $35-42 \%$ when the soil was kept near saturation and by $47 \%$ and $51 \%$ when the soil dried out to 20 and $40 \mathrm{kPa}$ moisture tension in the root zone, respectively.

Irrigation water use of rice grown on beds with intermittent irrigation until 2 weeks before panicle initiation, followed by continuous flooding, was similar to water use of dry-seeded rice on the flat surface with continuous flooding commencing about 1 month after sowing (Beecher et al., 2006). 
Management of cracked soils for water saving during land preparation

Tuong et al., (1996) reported that bypass flow accounted for $41 \pm 57 \%$ (equivalent to about $100 \mathrm{~mm}$ of water) of the total water applied in the field during land soaking. Water loss throughout the period of land preparation may be much greater than this, because cracks may not close after rewetting [46], and bypass flow may continue until soil is repuddled. This might explain the very high percolation losses during land preparation, accounting for up to $40 \%$ of the total water supplied for growing a rice crop. Reducing these losses will contribute greatly to improving water-use efficiency of rice. Straw mulching helped conserve moisture in the soil profile reduced crack development during the fallow period but did not reduce the bypass loss during land preparation. Shallow tillage formed small soil aggregates, which blocked and impeded water flow in the cracks and reduced the amount of water that recharged the groundwater via the bottom of the cracks and crack faces. Water was, therefore, retained better in the topsoil. Shallow surface tillage could reduce about $31 \pm 34 \%$ of the water input for land preparation, equivalent to a saving of $108 \pm 117 \mathrm{~mm}$ of water depth and shortened time required for land preparation. Water savings during land preparation may increase the service area of an irrigation system.

De Maria, (2015) also found that the possible effects on the hydraulic conductivity of variations of the water viscosity triggered by fluctuations of the water temperature. The irrigation requirements of rice are clearly not only determined by the water regime that is adopted either traditional flooding or nor only by the mere granulometry of the soil where rice is grown. Even when the very same regime is applied to the very same field, a significant inter-annual variability my occur in response to variations of environmental factors including groundwater levels, changes in the soil structure, meteorological conditions also prior to crop establishment and biotic factors. Values of water use efficiencies (evapotranspiration over net water input) and water productivity (grain yield over net water input) were therefore in the order WFL < DFL < DIR. The latter reached a water use efficiency of $0.56 \mathrm{~mm}$ $\mathrm{mm}^{-1}$ and a water productivity of $0.88 \mathrm{~m}^{3} \mathrm{ha}^{-1}$. Considering the values of water use indicators, the best performance was achieved by intermittent irrigated rice. The intermittent irrigation of dry-seeded rice and delayed flooding enabled to achieve higher water productivities than traditional flooding in both the years we considered (water productivities in the order: Intermittent Irrigation > Delayed flooding > Traditional Flooding). However, focussing on just a synthetic index could be indeed reductive. Variations were attributed to a combination of abiotic and biotic factors including the groundwater level at the beginning of the rice season, the soil moisture antecedent to the tillage operations; the rainfall intensity occurred between soil tillage and the first irrigation; and the possible occurrence of preferential macro-pore fluxes due the activity of earthworms.

Shantappa et al., (2014) conducted a field experiment at Hyderabad based on the different water levels and noticed that continuous submergence showed significantly higher quantity of water applied $(1433 \mathrm{~mm})$ than alternate wetting and drying $(1151 \mathrm{~mm})$ and saturation $(960 \mathrm{~mm})$. Recommended submergence of $2-5 \mathrm{~cm}$ water level as per crop stage consumed more water (1819.7 $\mathrm{mm}$ ) in field experiment on sandy loam soil at Hyderabad than irrigation of $5 \mathrm{~cm}$, when water level falls below $5 \mathrm{~cm}$ from soil surface in field water tube $(1271.7 \mathrm{~mm})$, irrigation of $5 \mathrm{~cm}$ at 3 days after disappearance of ponded water $(1154.7 \mathrm{~mm})$ and irrigation of $5 \mathrm{~cm}$, when water level falls below $10 \mathrm{~cm}$ from soil 
surface in field water tube treatments were recorded least water consumption $(1085 \mathrm{~mm})$ among different irrigation regimes (Sathish et al., 2017). The irrigation water applied effective rainfall and seasonal volume of water input varied from 708 to $1390 \mathrm{~mm}, 216$ to $300 \mathrm{~mm}$ and 1048 to $1646 \mathrm{~mm}$, respectively on pooled basis. Whereas, the effective rainfall was varied between 238 to $300 \mathrm{~mm}$ suggesting that the crop in AWD irrigation regimes used large proportion of total rainfall received relative to continuous submergence treatment. Whereas, the total water input amounted to 1056 to $1626 \mathrm{~mm}$, 1013 to $1667 \mathrm{~mm}$ and 1048 to $1646 \mathrm{~mm}$ in 2013, 2014 and on pooled basis, respectively (Kishore et al., 2017). Bouman and Tuong (2007) reported that total (irrigation + rainfall) water inputs decreased by around 1530 per cent without a significant impact on yield (Fig. 1-5).
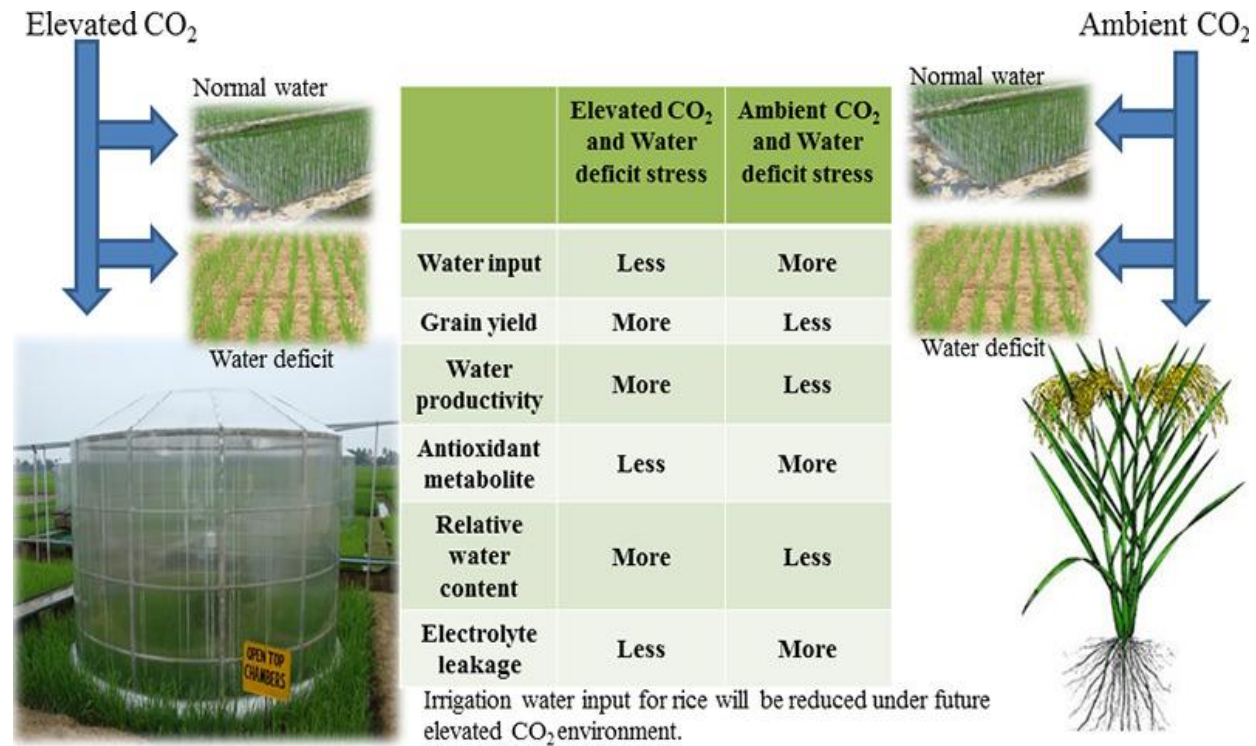

Physiological changes occurring under elevated $\mathrm{CO}_{2}$ helped the rice plant in mitigating the negative effects of water deficit stress.

Fig.1 Description of different water efficient regimes (Mao Zhi, 2000)

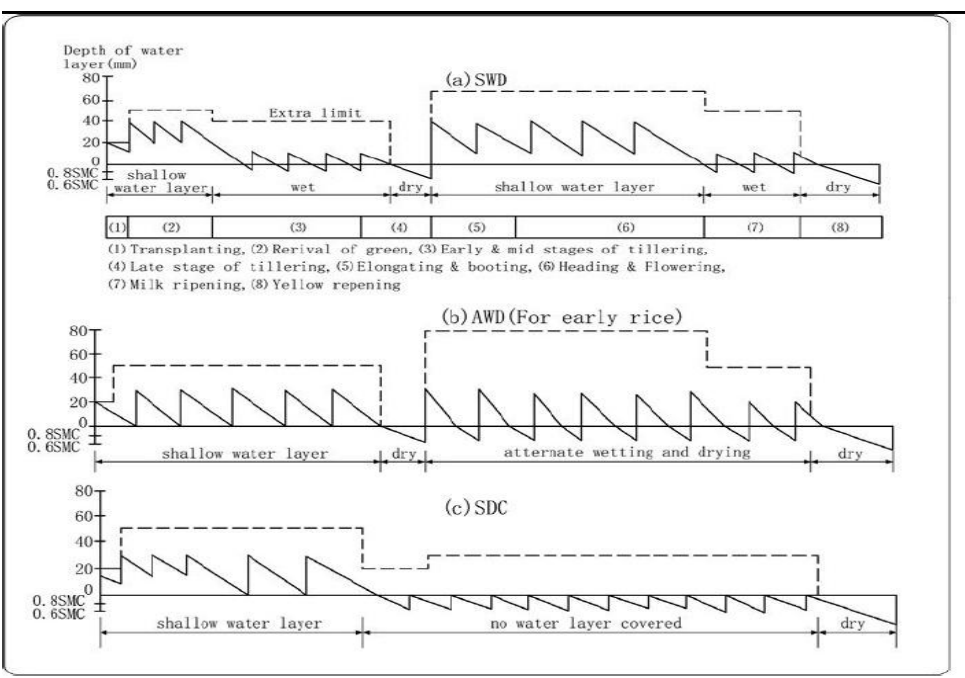


Fig.2 Projected water scarcity in 2025 in (a) wet season (summer) irrigated rice and (b) dry season irrigated rice areas in asia
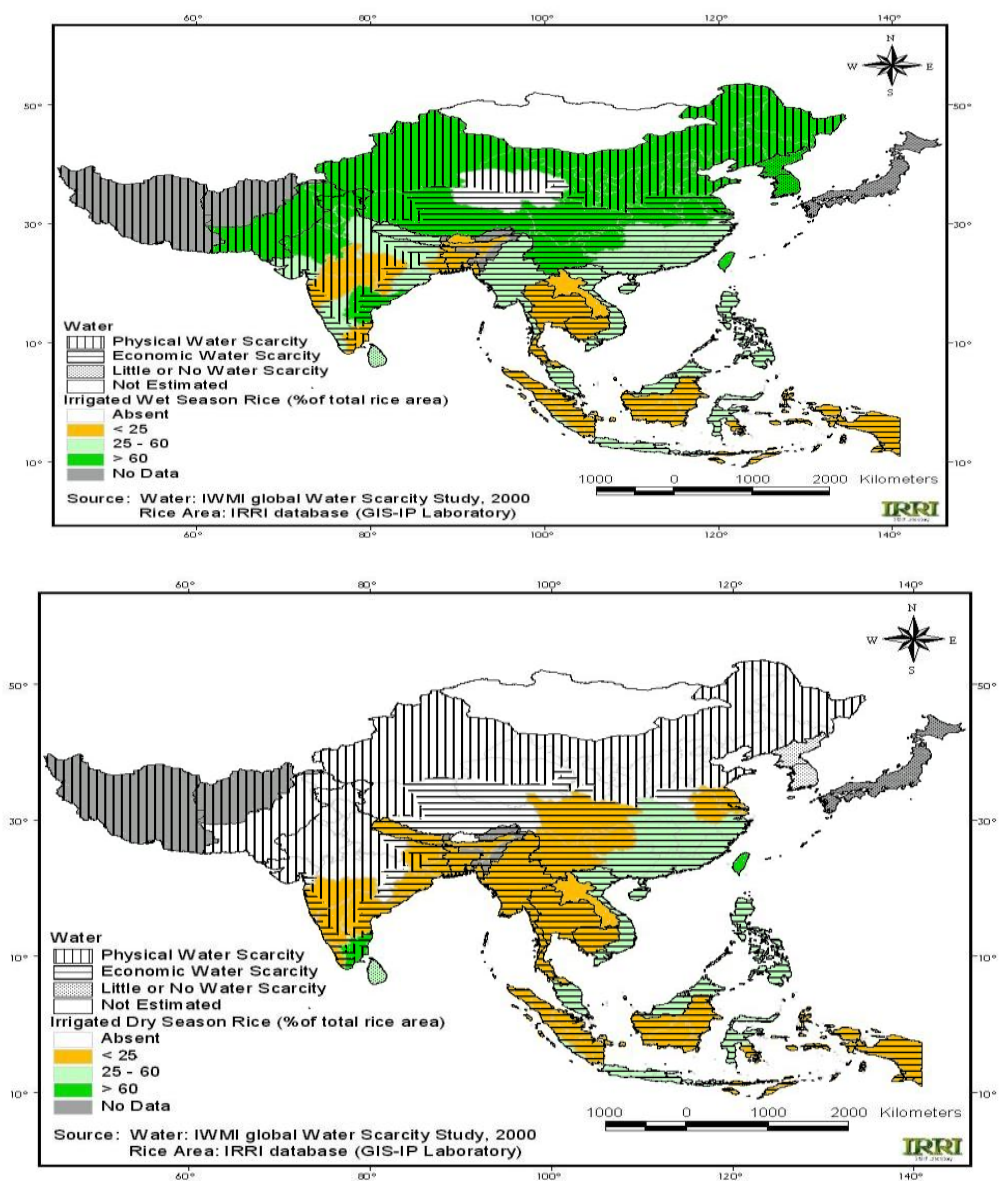

Fig.3(a) Multiple indicators of long-term performance of different scenarios. Performance metrics included wheat yield, rice equivalent yield in kharif season and system-level yield, irrigation water, net income, energy use, and global warming potential of cropping system

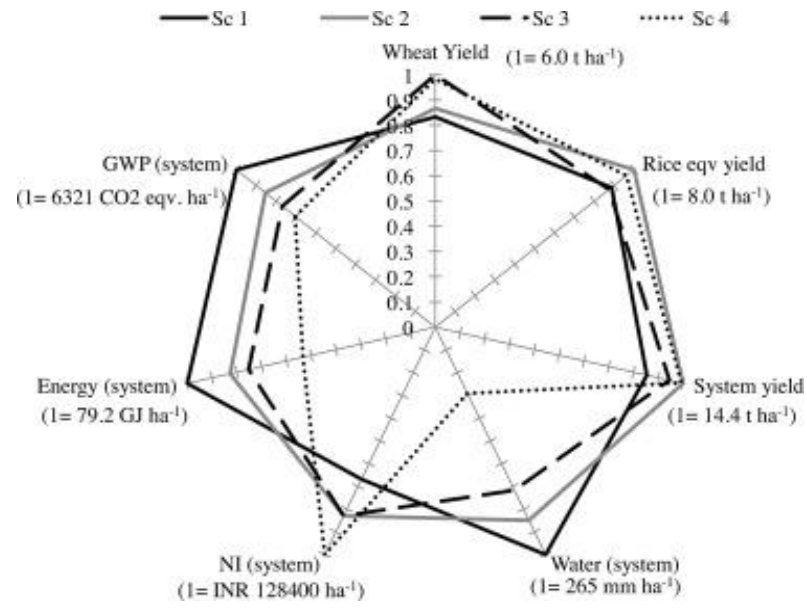


Fig.3(b) Irrigation water productivity (IWP) of major tillage and crop establishment methods in rice

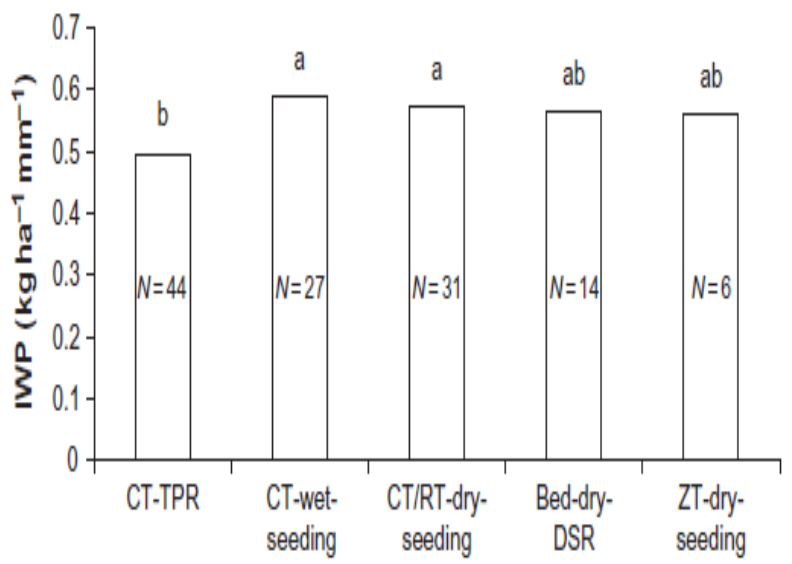

Fig.4 Various cultural activities, including irrigation schedules of puddled transplanting (A), direct wet seeding (B), and direct dry seeding (C). modified from Tabbal et al., (2002)

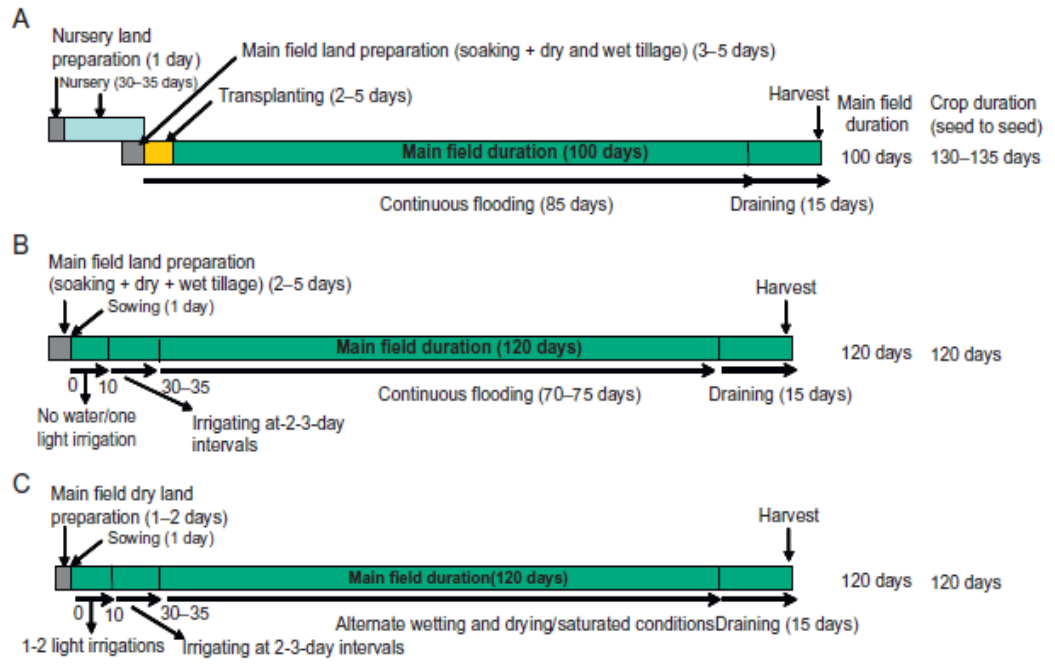

Fig.5 Water fluxes and storages in flooded (on the left) and aerobic (on the right) rice fields)

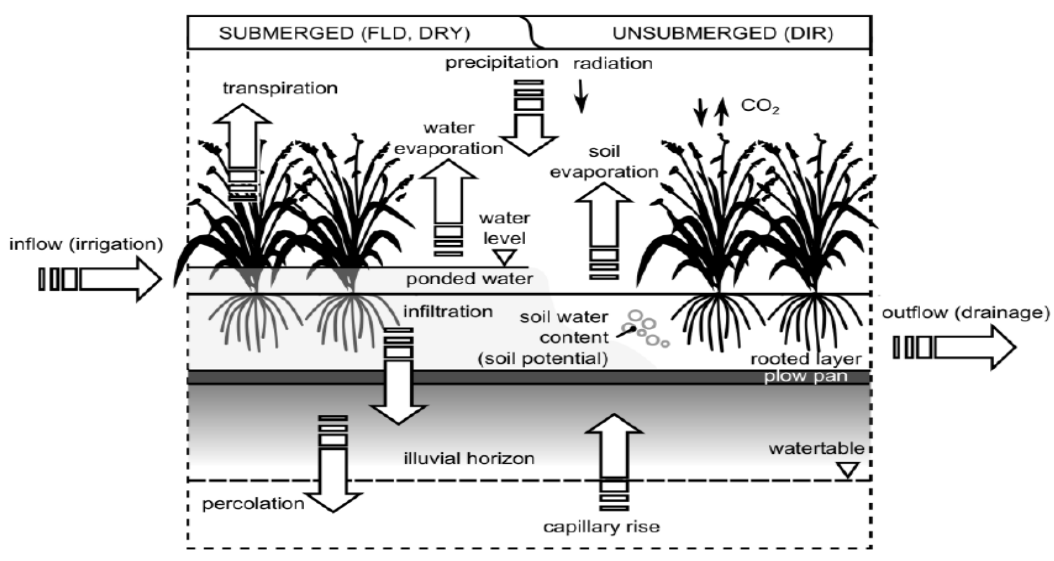


Continuous water submergence recorded more irrigation requirement $(1,200$ and 1,080 $\mathrm{mm}$ ) compared with 1 - day drainage (840 and $680 \mathrm{~mm}$ ) and 3- day drainage (600 and 560 $\mathrm{mm}$ in first and second year of study, respectively). Water application during rice cultivation has certain degree of changeability and flexibility. Reductions in irrigation water in AWD by 40-50 per cent, 20-50 per cent and over 50 per cent, respectively compared to continuous flooding of rice crop were noticed respectively by Keisuke et al., 2007, and Zhao et al., 2010. Continuous submergence consumed highest total water use $(122.2 \mathrm{~cm})$ produced the lowest grain

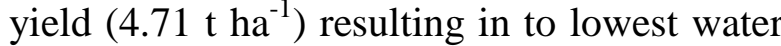
use efficiency $\left(84.34 \mathrm{~kg} \mathrm{ha}^{-1} \mathrm{~cm}\right)$. On the contrary, application of irrigation water to 5 cm depth when water level in PVC pipe fell to $15 \mathrm{~cm}$ below ground level gave the highest yield (5.69 $\mathrm{t} \mathrm{ha}^{-1}$ ) consequently the highest water use efficiency $\left(85.55 \mathrm{~kg} \mathrm{ha}^{-1} \mathrm{~cm}\right)$ with quite a large water saving $(15 \mathrm{~cm})$ compared to continuous submergence (Rahman and Shiekh, 2014). There was saving of water by $36.5,28.5$ and 40.4 per cent respectively compared to continuous submergence, though there was reduction in grain yield by $5.4,6.5$ and 12.3 per cent due to irrigation of $5 \mathrm{~cm}$ at 3 DADPW, irrigation of $5 \mathrm{~cm}$ when water falls below $5 \mathrm{~cm}$ from soil surface in field water tube and irrigation of $5 \mathrm{~cm}$ when water falls below $10 \mathrm{~cm}$ from soil surface in field water tube, respectively (Sathish et al., 2017).

The water productivity of rice is much lower than those of other crops. On an average, 2500 litres of water is used, ranging from 800 litres to more than 5000 litres to produce one $\mathrm{kg}$ of rice (Bouman, 2009). In general irrigation water productivity in continuously flooded rice found to be typically ranges between $0.2-0.4 \mathrm{~kg} \mathrm{~m}^{-3}$ of grain water in India assessed through secondary data and remote sensing technique. Rice irrigation water productivity was found highest in Jharkhand $\left(0.75 \mathrm{~kg} \mathrm{~m}^{-3}\right)$ followed by Chhattisgarh $\left(0.68 \mathrm{~kg} \mathrm{~m}^{-3}\right)$ and Bihar $(0.48 \mathrm{~kg}$ $\mathrm{m}^{-3}$ ) among different states in India and lowest was Maharashtra $\left(0.17 \quad \mathrm{~kg} \mathrm{~m}^{-3}\right)$ followed by Punjab $\left(0.22 \mathrm{~kg} \mathrm{~m}^{-3}\right)$. Where as in Telangana and Andhra Pradesh irrigation water productivity for rice found was 0.30 and $0.31 \mathrm{~kg} \mathrm{~m}^{-3}$ while physical water productivity was 0.46 and $0.44 \mathrm{~kg} \mathrm{~m}^{-3}$ respectively (Sharma et al., 2018). Water productivity of continuous submergence $(0.56$ $\mathrm{kg} \mathrm{m}^{-3}$ ) was lowest as compared to AWD Flooding to a water depth of $5 \mathrm{~cm}$ when water level drops to $10 \mathrm{~cm}$ below ground level $(0.94$ $\mathrm{kg} \mathrm{m}^{-3}$ ) (Kishor et al., 2017).

The irrigation schedule of one day after disappearance of ponded water consumed 604 $\mathrm{mm}$ less irrigation water and recorded higher water use efficiency (76 kg ha ${ }^{-1}$ day $^{-1}$ ) when compared to irrigating a continuous submergence in rice at Chhattisgarh (Pandey et al., 2010). Rezaei et al., (2009) stated that longer irrigation interval (5 and 8 days) decreased the water use, by 40 and 60 per cent, respectively in comparison to full irrigation, but increased the water productivity without any yield loss.

In conclusion, water is undoubtedly one of the most precious resources; however water is becoming increasingly scarce globally. Rice production and food security largely depend on the irrigated lowland rice system, but whose sustainability is threatened by fresh water scarcity, water pollution and competition for water use. Irrigation water saving strategies in rice production is becoming increasingly important to identify effective and sustainable crop production and management practices. In addition, these practices should be adopted in production agriculture. Thus, local data and information evaluating crop performance under different 
irrigation levels for different genotypes is critical for the success of this adoption. However, the technology practices are challenging due to differences in soil type, climate, management practices, and other factors. In irrigated systems, particular attention is to be given to improving quality water services at field level, which includes much improved water supplies in terms of flexibility and reliability, as well as access to sufficient drainage when required. Otherwise, none of the field level options would be effective. The modernization tools and concepts have been successfully introduced in rice irrigated systems and it is believed that they would greatly facilitate the adoption of feasible strategies for system modernization.

Water savings ranged from $12 \%$ to $35 \%$ depending on type of DSR. Water savings in different types of DSR ranked in the following order: CT wet-seeding < CT-dryseeding $=$ ZT-dry-DSR $<$ Bed-dry-DSR . Reduces irrigation water loss through percolation due to fewer soil cracks. DSR sowing is more cost effective technology as B: C varies from 2.29-3.12 as compared to transplanting (1.93-2.66). Moreover, water productivity is high in DSR and exceeds corresponding values in transplanting by $>25 \%$. The promising approaches are to improve water management to bridge the yield gap, by use of advanced strategies and technologies that are developed location specific. In addition, technology transfer and adoption in conjunction with manpower development are necessary elements supplement to the success, and has to be carried on by the local governments. The location specific and socio-economic circumstances of rice ecology determine the degree of freedom for effective intervention in the water resource system and management scheme. Moreover, systematic views considering vary levels and measure options are complemented by a set of related strategies and technologies. With the flexibility and reliability, such an integrated water management approach should be the appropriate answer to rice water management that would provide a change to really improve irrigation efficiency and water productivity now and the future. Such intelligent approach merits the full attention of all stakeholders and is worthwhile to point out for development. None the less, improved water management in rice production systems is likely to be an important item on the menu for a sustainable food future.

\section{References}

Anboumozhi, V.E., Hamaji and T. Tabuchi, 1998. Ruce comply and yield as influenced by changes in ponding water depth, water refine and fertigation level. Agri Water Manage, 37: 241-253.

Avil Kumar, K., and Rajitha, G. 2019. Alternate Wetting and Drying (AWD) Irrigation - A Smart Water Saving Technology for Rice: A Review. Int. J. Curr. Microbiol. App. Sci. 8 (03):2561-2571.

Balasubramanian, R., Krishnarajan J, Ramesh S., 2001. Economical use of water for direct-seeded rice. Rice research for food security and poverty alleviation. Proceedings of International Rice Research Conference. Los-Banos, Philippines, 31-March-3-April,-2000, 2001, 511-520.

Barker, R., Dawe D, Tuong TP, Bhuiyan SI, Guerra LC. 1998. The outlook for water resources in the year 2020: Challenges for research on water management in rice production. In: Assessment and Orientation. Towards the $21^{\text {st }}$ Century, Proceedings of $19^{\text {th }}$ Session of the International Rice Commission, 7-9 September 1998, Cairo, Egypt. Food and Agricultural Organization, Rome,96-109 
Beecher, et al., 2006. Effect of raised beds, irrigation and nitrogen management on growth, water use and yield of rice in south-eastern Australia. Aust. J. Exp. Agric. 46: 1363-1372.

Belder, P., Bouman BAM, Spiertz JHJ. 2007. Exploring options for water savings in lowland rice using a modelling approach. Agr Syst 92: 91-114.

Borrell, et al., 1997. Improving efficiency of water use for irrigated rice in a semiarid tropical environment. Field Crops Res. 52: 231-248.

Bouman, B.A.M., 2009. How much does rice use? Rice Today. 8: 28-29.

Bouman, B.A.M., and Tuong, T.P. 2007. A conceptual framework for the improvement of crop water productivity at different spatial scales. Agri Syst. 93: 43-60.

Bouman, B.A.M., Wopereis, M.C.S., Kropff, M.J., ten Berge, H.F.M., Tuong, T.P., 1994. Understanding the water use efficiency of flooded rice fields. II. Percolation and seepage losses. Agri Water Manage, 26: 291-304.

Bouman, BAM., Peng S, Castaneda AR, Visperas RM. 2005. Yield and water use of tropical aerobic rice systems. Agri Water Manage. 74:87-105.

Cabangon, R.J., Tuong, T.P., Abdullah, N.B. 2002. Comparing water input and water productivity of transplanted and direct-seeded rice production systems. Agri Water Manage. 57: 11-31.

De Datta, S., K.1981. Principles and Practices of Rice Production. John Wiley and Sons, New York. Pp 618.

De Maria, S.C., 2015. Strategies to increase water productivity in irrigated rice systems: is reducing water inputs the key? PhD Thesis. Department of Environmental Sciences, University of California Riverside, Riverside, California, USA.

DID and JICA. 1998. The study on modernization of irrigation water management system in the granary areas of Peninsular Malaysia. Nippon Koei Co., Ltd, 1998.

FAO. 2002. Design, policy management and performance of irrigation projects. Bangkok

Gathala M K., Ladha J K, Kumar V, Saharawat Y S, Kumar V, Sharma P K, Sharma S and Pathak H. 2011. Tillage and crop establishment affects sustainability of South Asian ricewheat system. Agron J. 103(4): 96171.

Gathala, M K., Kumar V, Sharma P C, Yashpal S, Saharawat, Jat H C, Mainpal-Singh, Kumar A, Jat M L, Humphreys E, Sharma D K, SheetalSharma and Ladha J K. 2014. Reprint of Optimizing intensive cereal-based cropping systems addressing current and future drivers of agricultural change in the North western IndoGangetic Plains of India. Agric Ecosys Environ 187: 33-46.

Gathala, M.K., Kumar, V., Sharma, P.C., Saharawat, Y.S., Jat, H.S., Singh, M., Kumar, A.,Jat, M.L., Humphreys, E., Sharma, D.K., Sharma, S., Ladha, J.K. 2013. Optimizing intensive cerealbased systems addressing current and future drivers of agricultural change in the north-western Indo-Gangetic Plains of India. Agri Ecosyst Environ. 177: 85-97.

Gupta, R K., Naresh R K, Hobbs P R and Ladha J K. 2002. Adopting conservation agriculture in the ricewheat system of the Indo-Gangetic Plains: New opportunities for saving water. In: Bouman B A M, Hengsdijk $\mathrm{H}$, Hardy B, Bindraban P S, Tuong T $\mathrm{P}$ and Ladha $\mathrm{J} \mathrm{K}$ (edS) Water wise rice production: Proceedings of the international workshop on water wise rice production, April 8-11, 2002, Los 
Baños, Philippines, Los Baños, Philippines: International Rice Research Institute.

Horie, T., Shiraiwa, T., Homma, K., Katsura, K., Maeda, S., Yoshida, H. 2005. Can yields of low land rice resume the increases that they showed in the 1980s? Plant Prod Sci 8: 259-274.

Huang, et al., 1999. Ecophysiological effect of dry cultivated and plastic filmmulched rice planting. Chin. J. Appl. Ecol. 10: 305-308.

Inthapan, P., Fukai, S. 1988. Growth and yield of rice cultivars under sprinkler irrigation in south eastern Queensland. II. Comparison with maize and grain sorghum under wet and dry conditions. Aust J Exp Agric. 28: 243248.

Jalota, S.K., Sood, A., Harman, W.L. 2006. Assessing the response of chickpea (Cicer aeritinum $\mathrm{L}$ ) yield to irrigation water on two soils in Punjab (India): a simulation analysis using the CROPMAN model. Agric. Water Manage, 79: 312-320.

Jat, M.L., Gathala, M.K., Ladha, J.K., Saharawat, Y.S., Jat, A.S., Kumar, V., Sharma, A.S., Gupta, R.K. 2009. Evaluation of precision land leveling and double zero-till systems in the rice-wheat rotation: Water use, productivity, profitability and soil physical properties. Soil Tillage Res. 105: 112-121

Jinsy VS., Pillai PS, Jacob J. 2015. Productivity analysis of aerobic rice in the lowlands of Southern Kerala. $J$ Tropical Agri. 53(1):1-7.

Kadiyala, MDM., Mylavarapu RS, ReddyGB, Reddy MD. 2012. Impact of Aerobic Rice Cultivation on Growth, Yield, and Water Productivity of Rice-Maize Rotation in Semiarid Tropics. Clim Water Manag. 104(6):1751-1765.

Keisuke, S., Yamaji, E., Sato, S., Budhiharto,
P.S and Mizoguchi, M. 2007. Sustainability of system of rice intensification: Benefits of SRI focusing on effects of intermittent irrigation on yield increase and water savings. In: Proceeding of PAWEES 2007: 6th International Conference on Sustainable Rural Development and Management, 25-37, Seoul National University, Seoul, Korea.

Kishor, M., Praveen Rao, V., Ramulu, V., Avil Kumar, $\mathrm{K}$ and Uma Devi, M.2017. Standardization of Alternate Wetting and Drying (AWD) method of water management in low land rice (Oryza sativa L.). Int J Plant Prod. 11(4):515-532.

Klemm, W., 1998. Water saving in rice cultivation. In: Assessment and orientation towards the $21^{\text {st }}$ century, Proceedings of $19^{\text {th }}$ Session of the International Rice Commission, 7-9 September 1998, Cairo, Egypt. FAO, Rome, 1998, 110-117.

Kreye, et al., 2007. Fluxes of methane and nitrous oxide in water-saving rice production in north China. Nutr. Cycl. Agroecosyst. 77: 293-304.

Kukal, S.S., and Aggarwal, G. C. 2003. Puddling depth and intensity effects in rice-wheat system on a sandy loam soil. I. Development of subsurface compaction. Soil Tillage Res. 72:1-8.

Kumar, R., Rana, N.S., Saharawat, Y.S., Amit Mishra, Kumar, V., Gathala, M.K., Kumar, R., and Dwivedi , A. Improvement in Water Productivity without Yield Penalty of Direct Seeded Rice under Micro Irrigation Systems and Tillage Options in IndoGengetic Plain of India. Int. J. Pure App. Biosci. 5 (1): 147-155

Ladha, J.K,. Yadvinder-Singh, Erenstein O and Hardy B. 2009. Integrated crop and resource management in the ricewheat systems of South Asia. 
International Rice Research Institute, Los Baños, Philippines.

Lin, et al., 2003. Saving water with the ground cover rice production system in China. In Technological and Institutional Innovations for Sustainable Rural Development." Conference on International Agricultural Research for Development. Deutscher Tropentag, 8-10 October 2003, Gottingen.

Lin, X.Q., Zhou, W.J., Zhu, D.F., Zhang, Y.B. 2005. Effect of SWD irrigation on photosynthesis and grain yield of rice. Field Crop Res. 94: 67-75.

Linquist, B., Snyder, R., Anderson, F. 2015. Water balances and evapotranspiration in water- and dry-seeded rice systems. Irrigation Science 33: 375-385

Lu, et al., 2000. The effects of irrigation regimes on the water use, dry matter production and physiological responses of paddy rice. Plant Soil 223: 207-216.

Mao Zhi, 2000. Water-efficient irrigation regimes of rice for sustainable increases in water productivity. In Proceedings of International Rice Research Conference, International Rice Research Institute, Laguna, Philippines

Marino, S., Aria, M., Basso, B., Leone, A.P., Alvino, A. 2014. Use of soil and vegetation spectroradiometry to investigate crop water use efficiency of a drip irrigated tomato. Eur. J. Agron. 59: 67-77

Masseroni, D., Ortuani, B., Corti, M., Gallina, P.M., Cocetta, G., Ferrante, A., Facchi, A. 2017. Assessing the reliability of thermal and optical imaging techniques for detecting crop water status under different nitrogen levels. Sustainability9: 1548.

Matsuo, N., and Mochizuki T. 2009. Growth and yield of six rice cultivars under three water saving cultivations. Plant Prod Sci. 12:514-525.

Naresh, R K., Gupta R K, Kumar A, Singh B, Prakash S, Kumar S, Rathi R C. (2011). Direct-seeding and reducedtillage options in the rice-wheat system of the Western Indo-Gangetic Plains. Int J Agri Sci, 7(1): 197-208.

Naresh, R K., Singh S P and Kumar V. 2013. Crop establishment, tillage and water management technologies on crop and water productivity in rice-wheat cropping system of North West India. Int J Life Sci Bt Pharm Res 2(3): 23748.

Naresh, RK., Tomar SS, Samsher P, Singh SP, Kumar D, Dwivedi A,Kumar V. (2014). Experiences with rice grown on permanent raised beds: effect of water regime and planting techniques on rice yield, water use, soil properties and water productivity. Rice Sci 21(3):170-180

O’Shaughnessy, S.A., Evett, S.R., Colaizzi, P.D., Howell, T.A. 2011. Using radiation thermography and thermometry to evaluate crop water stress in soybean and cotton. Agric. Water Manag. 98: 1523-1535

O'Shaughnessy, S.A., Evett, S.R., Colaizzi, P.D., Howell, T.A. 2012. A crop water stress index and time threshold for automatic irrigation scheduling of grain sorghum. Agric. Water Manag. 107: 122-132.

O'Toole, J.C. 1982. Adaptation of rice to drought-prone environment. In Drought Resistance in Crops with Emphasis on Rice pp.195-213. International Rice Research Institute, Manila, Philippines.

Pandey, N., Verma, A.K and Tripathi, R.S. 2010. Response of hybrid rice to scheduling of nitrogen and irrigation during dry season. Oryza. 47(1): 34- 
37.

Qinghua Shi, Xiaochun Muying Li, Xueming Tan, and Fengfeng Xu, 2002. Effect of different water management practices on rice growth. Proceedings of $a$ thematic workshop on water-wise rice production, 8- 11 April, 2002 at IRRI headquarters in Los Banos, Philippines.

Rahman, R., and Sheikh, H.B.2014. Effect of alternate wetting and drying (AWD) irrigation for Boro rice cultivation in Bangladesh. Agri, Forestry Fisheries. 3 (2): 86-92.

Raine, SR., Meyer WS, Rassam DW, Hutson JL, Cook FJ. 2007. Soil-water and solute movement under precision irrigation: knowledge gaps for managing sustainable root zones. Irrigation Science 26: 91-100

Reddy MD, Reddy SN, Ramulu V. 2010. Evaluation of rice cultivars for aerobic and transplanted conditions. Agri Sci Digest. 30(2):129-32

Rezaei, M., Vahed, H.S., Amiri, E., Motamed, M.K and Azarpour, E. 2009. The effect of irrigation and nitrogen management on yield and water productivity of rice. World Appl Sci J. 7(2): 203-210.

Rowshon, M K., and Amin M S M. 2010. GIS-based irrigation water management for precision farming of rice. Int J Agric \& Biol Eng. 3(3): 2735.

Sandhu, S.S.,Mahal,S.S., Vashist, K.K., Buttar, G.S., Brar, A.S. and Singh, Maninder. 2012. Crop and water productivity of bed transplanted rice as influenced by various levels of nitrogen and irrigation in northwest India. Agric Water Manage 104:3239

Sathish, A., Avil Kumar, K., Raghu Rami Reddy, P and Uma Devi, M. 2017. Effect of Different Crop
Establishment Methods and Irrigation Regimes on Rice (Oryza sativa L.) Yield and Water Use Efficiency. Int J Curr Microbio Appl Sci. 6 (9):90-95.

Sattar, M.A., M. A. Rashid, M. N. Hassan, H. R. Molla, A. K. Khan, S. Parveen, D.Roy and H. Mahamud. 2009. Alternate Wetting and Drying Technology for Water Saving in Boro Rice Production for the Selected Locations of Bangladesh. Paper presented in of the National Workshop on Adoption and Success of AWD Technology for Rice Production held on 15 July 2009 at the BRRI, Gazipur.

Seckler, D. 1999. Revisiting the "IWMI Paradigm:" Increasing the efficiency and productivity of water use. Water Brief 2. Colombo, Sri Lanka, International Water Management Institute

Shantappa, D., Tirupathaiah, K., Yella Reddy, K., Sandhyarani, K., Mahendra Kumar, R and Kadasiddappa, M. 2014. In: International Symposium on Integrated Water Resources Management. CWRDM, Kozhikode, India, 19-21.

Shekara, Sharnappa and Krishnamurthy. 2010. Effect of irrigation schedules on growth and yield of aerobic rice (Oryza sativa $\mathrm{L}$ ) under varied levels of farmyard manure in Cauvery command area. Indian J. Agron., 55 (1): 35-39.

Singh S, Sharma RK, Singh G, Singh SS, Singh UP, Gill MS, et al., 2005. Direct Seeded Rice: A Promising Resource Conserving Technology. Rice-Wheat Consortium for IndoGangetic Plains, September, 2005.

Singh, A., Kumar R, Kang J. S. 2014. Tillage System, Crop Residues and Nitrogen to Improve the Productivity of Direct Seeded Rice and Transplanted Rice. Current Agric Res 2 (1): doi 
:http://dx.doi.org/10.12944/CARJ.2.1. 03

Singh, et al., 2001. The effect of seeding and tillage methods on productivity of rice-wheat cropping system. Soil Tillage Res. 61: 125-131.

Sritharan, N., Vijayalakshmi C, Selvaraj PK.2010. Effect of micro-irrigation technique on physiological and yield traits in aerobic rice. Int $J$ Agri, Environ Biotech. 3(1):26-28.

Sudhir-yadav, Gill, G., Humphrey, E., Kukal, S.S., Walia, U.S. 2011. Effect of water management on dry seeded and puddle transplanted rice Part 1: Crop Performance. Field Crops Res. 120: $112-122$.

Sudhir-yadav, Humphrey, E., Gill, G., Kukal, S.S., Rangarajan, R. 2011. Effect of water management on dry seeded and puddle transplanted rice Part 2: Water balance and water productivity. Field Crops Res. 120: 123-132.

Tabbal, D.F., Bouman, B.A.M., Bhuiyan, S.I., Sibayan, Sattar, M.A. 2002. On farm strategies for reducing water input in irrigated rice: Case study in Philippines. Agri Water Manage. 56: 93-111.

Tuong, et al., 1996. Quantifying flow processes during land soaking of cracked rice soils. Soil Sci. Soc. Am. J. 60: 872-879.

Wang, HQ, Bouman, BAM, Zhao DL, Wang
C, Moya PF. 2002. Aerobic rice in northern China: opportunities and challenges. In: Bouman BAM, Hengsdijk, H, Hardy B, Bindraban PS, Tuong TP, Ladha JK (Eds.). Procedings of the International Workshop on Water-wise Rice Production, 8-11 April. International Rice Research Institute, Los Banos, Philippines, 2002, 143-54.

Yadav, S., Gill G, Humphreys E, Kukal SS, Walia US. 2011. Effect of water management on dry direct seeded rice and puddled transplanted rice Part 2: Water balance and water productivity. Field Crops Res. 120:123-132.

Zhang, H., Xue, Y., Wang, Z., Yang, J., Zhang, J. 2009. Alternate wetting and moderate soil drying improves root and shoot growth in rice. Crop Sci. 49: 2246-2260

Zhao, L.M., Wu, L.H., Li, Y.S., Sarkar, A., Zhu D.F and Uphoff, N. 2010. Comparisons of yield, water use efficiency, and soil microbial biomass as affected by the system of rice intensification. Comm Soil Sci Plant Anal. 4(1): 1-12.

Zhao, Y., De Maio M, Vidotto F, Sacco D. 2015. Influence of wet-dry cycles on the temporal infiltration dynamic in temperate rice paddies. Soil Tillage Res. 154: 14-21.

\section{How to cite this article:}

Mahajan, N.C., R.K. Naresh, S.K. Tomar, Vivek, Kancheti Mrunalini, M. Sharath Chandra and Lingutla Sirisha. 2019. More Rice, Less Water-Precision Water Management Approaches for Increasing Water Productivity in Irrigated Rice-Based Systems under North IGP: A Review. Int.J.Curr.Microbiol.App.Sci. 8(05): 1727-1747. doi: https://doi.org/10.20546/ijcmas.2019.805.200 